\title{
Reposisi Bantuan Hukum Secara Probono Oleh Organisasi Bantuan Hukum Dalam Kajian Undang-Undang Nomor 16 Tahun 2011 Tentang Bantuan Hukum
}

\author{
Patria Palgunadi \\ Magister Hukum Universitas Semarang
}

\begin{abstract}
ABSTRAK
Penelitian ini bertujuan untuk mengetahui dan menganalisa Reposisi Bantuan Hukum Secara Probono oleh organisasi bantuan hukum. Bantuan hukum merupakan instrumen penting dalam sistem peradilan karena merupakan bagian dari perlindungan hak asasi manusia bagi setiap individu. Bantuan hukum diatur di beberapa UndangUndang namun secara prinsip hanya diatur di dua Undang-Undang yaitu UndangUndang Nomor 18 Tahun 2003 Tentang Advokat dan Undang-Undang Nomor 16 Tahun 2011 Tentang Bantuan Hukum, hal ini yang akan menjadi obyek penelitian dalam tesis ini tentang reposisi bantuan hukum probono. Penelitian ini menggunakan metode pendekatan yuridis normatife atau hukum normatif, Didalam Undang-Undang Nomor 18 Tahun 2003 Tentang Advokat Adalah sudah merupakan kewajiban dan tanggung jawab bagi seorang advokat untuk melakukan bantuan hukum cuma-cuma kepada masyarakat tidak mampu secara ekonomi bahkan seorang Advokat dilarang menolak penanganan perkara yang dimohonkan oleh orang atau kelompok yang tidak mampu, dan ini adalah pengabdian bagi advokat. Delapan tahun setelah UndangUndang Nomor 18 Tahun 2003 Tentang Advokat disyahkan, muncul Undang-Undang Nomor 16 Tahun 2011 Tentang Bantuan Hukum (UU Bankum). Hadirnya UU Bankum memberikan ruang bagi Pemberi Bantuan Hukum dalam hal ini Organisasi Bantuan Hukum untuk dapat mengakses pendanaan atas penyelenggaraan bantuan hukum cuma-cuma dari APBN, APBD, Hibah/ Sumbangan serta Sumber lain yang sah dan tidak mengikat. Dengan dibukanya akses pendanaan atas penyelenggaraan bantuan hukum pada UU Bankum telah menggeser semangat bathin pengabdian Probono Publico pada Undang-Undang Nomor 18 Tahun 2003 Tentang Advokat, sehingga posisi Probono Publico menjadi bias.
\end{abstract}

\section{Kata kunci : Bantuan hukum; probono; advokat}




\title{
Legal Aid Repositioning by Legal Aid Organizations in the Study of Law Number 16 of 2011 concerning Legal Aid
}

\author{
Patria Palgunadi \\ Master of Law, University of Semarang
}

\begin{abstract}
This study aims to determine and analyze the Probono Legal Aid Repositioning by legal aid organizations. Legal aid is an important instrument in the justice system because it is part of the protection of human rights for every individual. Legal aid is regulated in several laws, but in principle it is only regulated in two laws, namely Law Number 18 of 2003 concerning Advocates and Law Number 16 of 2011 concerning Legal Aid, this will be the object of research in this thesis. about the repositioning of probono's legal aid.This research uses the normative juridical approach method or normative law. In Law Number 18 Year 2003 About Advocates It is an obligation and responsibility for an advocate to provide free legal assistance to economically incapable people and even an Advocate is prohibited from refusing to handle cases filed by individuals or groups who are unable, and this is devotion to advocates. Eight years after Law Number 18 of 2003 concerning Advocates was ratified, Law Number 16 of 2011 concerning Legal Aid (Law of the Bankum) appeared. The presence of the Bankum Law provides a space for Legal Aid Providers in this case the Legal Aid Organization to be able to access funding for the implementation of free legal assistance from the state budget, regional budget, grants I donations as well as other legal and non-binding sources. With the opening of access to funding for the implementation of legal aid in the Law on Bankum has shifted the inner spirit of Probono Publico's devotion to Law Number 18 Year 2003 About Advocates, so that Probono Publico's position is biased.
\end{abstract}

Keywords: Legal aid; pro bono; advocate 


\section{A. PENDAHULUAN}

Indonesia merupakan negara yang menganut sistem negara hukum (rule of law). Negara hukum di sini mengisyaratkan bahwa dimana kedudukan seluruh warganya sama di depan hukum tanpa terkecuali . Selain menganut sistem rule of law, Indonesia juga merupakan negara yang berdasar hukum (recht staat) Dasar pijakan bahwa negara Indonesia adalah negara hukum tertuang dalam Undang-Undang Dasar 1945, 1 yang menyebutkan bahwa "Negara Indonesia adalah Negara Hukum". Dimasukkannya ketentuan ini ke dalam bagian pasal Undang-undang Dasar 1945 menunjukkan semakin kuatnya dasar hukum serta menjadi amanat Negara.

Hal tersebut secara tegas dinyatakan juga dalam Undang-Undang Dasar Negara Republik Indonesia tahun 1945 Pasal 27 ayat (1), yang berbunyi: "Segala warga negara bersamaan kedudukan nya dalam hukum dan pemerintahan serta wajib menjunjung hukum dan pemerintah itu dengan tidak ada kecualinya”, dan ditegaskan kembali dalam Pasal 28D ayat (1) yang menyebutkan "Setiap orang berhak atas pengakuan, jaminan, perlindungan dan kepastian hukum yang adil serta perlakuan yang sama dihadapan hukum". Persamaan di hadapan hukum tersebut dapat terealisasi dan dapat dinikmati oleh masyarakat apabila ada kesempatan yang sama untuk mendapatkan keadilan. Persamaan dihadapan hukum harus diiringi pula dengan berbagai kemudahan untuk mendapatkan keadilan, termasuk didalamnya pemenuhan hak atas bantuan hukum.

Adanya ketidakmampuan masyarakat secara finansial untuk menuntut haknya sesuai dengan prosedur hukum, menuntut untuk diadakannya suatu kebijaksanaan sehingga dapat mengajukan suatu perkara perdata dengan tidak terbentur oleh biaya, khususnya dalam berperkara perdata, oleh karena itu diperlukan suatu prosedur untuk mengajukan perkara secara cuma-cuma / tidak perlu membayar panjer perkara (prodeo). Sehingga bagi pihak yang kurang mampu, dapat mengajukan gugatan secara cuma-cuma yang disebut dengan berperkara secara prodeo. Hal tersebut sesuai dengan asas trilogi peradilan yaitu peradilan cepat, sederhana dan murah. ${ }^{2}$ Frans

\footnotetext{
${ }^{1}$ Pasal 1 ayat 3 Undang-Undang Dasar 1945

${ }^{2}$ Sudikno Mertokusumo, 1998, Hukum Acara Perdata Edisi kelima, Liberty Yogyakarta, hlm. 16
} 
e-ISSN : 2621-4105

Hendra Winarta mengemukakan bahwa seringkali pihak yang miskin karena tidak tahu hak-haknya sebagai tergugat, diperlakukan tidak adil atau dihambat haknya untuk didampingi advokat. ${ }^{3}$ Hal ini tentu saja sangat merugikan pihak yang menuntut hak nya dan yang nantinya di proses di pengadilan. Untuk menghalangi terjadinya hal tersebut, dibutuhkan suatu lembaga atau organisasi hukum yang memperjuangkan keadilan dan penegakan hukum seperti Lembaga Bantuan Hukum (LBH) yang mendampingi klien atau pihak yang dirugikan hak nya, dengan catatan klien atau pihak yang akan didampingi perkaranya lemah secara ekonomi.

Pasca ditetapkannya Undang-Undang Nomor 18 Tahun 2003 Tentang Advokat, Advokat mempunyai kedudukan yang cukup eksklusif, Pasal 5 ayat (1) UndangUndang Nomor 18 Tahun 2003 merumuskan Advokat berstatus sebagai penegak hukum, bebas dan mandiri yang dijamin oleh hukum dan peraturan perundangundangan. ${ }^{4}$ Undang-Undang Advokat juga memandatkan Advokat untuk wajib memberikan layanan bantuan hukum kepada masyarakat atau kelompok yang tidak mampu secara ekonomi sesuai dengan Undang-undang Nomor 18 tahun 2003 tentang Advokat Pasal 22 Ayat (1 dan 2).

Selain Undang-Undang Nomor 18 Tahun 2003, sebenarnya Negara telah mengatur hak konstitusi warga negaranya atas persamaan hak dimuka hukum dibeberapa perundang-undangan yaitu terdapat pada :

1. Undang- Undang Nomor 8 Tahun 1981 tentang Hukum Acara Pidana atau Kitab Undang-Undang Hukum Acara Pidana (KUHAP) terdapat dalam Pasal 54, Pasal 56 ayat (1 dan 2), Pasal 114;

2. Undang-Undang Nomor 48 Tahun 2009 Tentang Kekuasaan Kehakiman yang mana masalah tentang bantuan hukum di atur tersendiri di dalam Bab XI Pasal 56 dan Pasal 57;

3. Undang-Undang Nomor 49 Tahun 2009 Tentang Peradilan Umum yang di bahas di Pasal 68B dan Pasal 68C;

${ }^{3}$ Frans Hendra Winarta, 2000, Bantuan Hukum Suatu Hak Asasi Manusia Bukan Belas Kasihan, Elex Media Komputindo, Jakarta, hlm. 96.

${ }^{4}$ Yusriyadi, 2017, Bantuan Hukum "Kajian Empiri Implementasi Ide-Ide Hukum”, Undip Press, Semarang, hlm. 75 
Delapan tahun setelah Undang-Undang Nomor 18 Tahun 2003 Tentang Advokat disyahkan, muncul Undang-Undang Nomor 16 Tahun 2011 Tentang Bantuan Hukum (UU Bankum). Hadirnya UU Bankum memberikan ruang bagi Pemberi Bantuan Hukum dalam hal ini Organisasi Bantuan Hukum untuk dapat mengakses pendanaan atas penyelenggaraan bantuan hukum cuma-cuma dari APBN, APBD, Hibah/ Sumbangan serta Sumber lain yang sah dan tidak mengikat.

Dengan dibukanya akses pendanaan atas penyelenggaraan bantuan hukum pada UU Bankum telah menggeser semangat bathin pengabdian Probono Publico pada Undang-Undang Nomor 18 Tahun 2003 Tentang Advokat, sehingga posisi Probono Publico menjadi bias.

\section{B. PERMASALAHAN}

Berdasarkan latar belakang masalah yang telah penulis paparkan di atas, maka permasalahan dalam penelitian ini adalah sebagai berikut:

1. Bagaimanakah konsep bantuan hukum secara probono berdasarkan Undangundang nomor 16 tahun 2011 tentang bantuan hukum dan Undang-undang nomor 18 tahun 2003 tentang Advokat?

2. Bagaimana reposisi bantuan hukum secara probono oleh organisasi bantuan hukum dalam kajian Undang-undang nomor 16 tahun 2011 tentang bantuan hukum?

\section{METODE PENELITIAN}

Penelitian ini menggunakan metode pendekatan yuridis normatife atau hukum normatif. Metode penelitian ini merupakan metode penelitian hukum kepustakaan dimana metode atau cara yang dipergunakan di dalam penelitian hukum dilakukan dengan cara meneliti bahan pustaka yang ada. ${ }^{5}$ Tahapan pertama penelitian hukum normatif adalah penelitian yang ditujukan untuk mendapatkan hukum obyektif (norma hukum), yaitu dengan mengadakan penelitian terhadap masalah hukum. Tahapan kedua penelitian hukum normatif adalah penelitian yang ditujukan untuk mendapatkan hukum subjektif (hak dan kewajiban). ${ }^{6}$

\footnotetext{
${ }^{5}$ Soerjono Soekanto dan Sri Mamudji, 2009, Penelitian Hukum Normatif Suatu Tinjauan Singkat, Cetakan ke-11, PT Raja Grafindo Persada, Jakarta, hlm. 13-14

${ }^{6}$ Hardijan Rusli, 2006, Metode Penelitian Hukum Normatif, Bagaimana, (Law Review Fakultas Hukum Universitas Pelita Harapan, Volume V No. 3, Jakarta, hlm. 50.
} 
e-ISSN : 2621-4105

Relevansi pendekatan penelitian ini adalah untuk menganalisis dan mengkaji reposisi bantuan hukum probono oleh organisasi bantuan hukum dalam Kajian Undang-Undang Nomor 16 Tahun 2011 Tentang Bantuan Hukum.

Spesifikasi penelitian ini adalah penelitian deskriptif analitis, yaitu suatu penelitian yang berusaha menggabarkan masalah hukum dan mengkajinya atau menganalisisnya sesuai dengan kebutuhan dari peneliti-an yang bersangkutan. ${ }^{7}$

Penelitian deskriptif analitis ini akan mempermudah mengetahui masalah (kasus) yang dihubungkan dengan fenomena atau gejala lain yang berhubungan dan menjelaskan reposisi bantuan hukum probono oleh organisasi bantuan hukum dalam kajian Undang-Undang Nomor 16 Tahun 2011 Tentang Bantuan Hukum.

Penelitian ini menggunakan teknik analisis Kualitatif Normatif. Teknik ini memanfaatkan data - data yang berupa peraturan perundang - undangan dan data kepustakaan lainnya. Data-data yang sudah didapatkan dari studi lapangan dan studi pustaka akan di kumpulkan dan dikelompokkan secara sistematis sesuai dengan fakta dan karakteristik objek yang diteliti secara tepat kemudian dianalisis secara kualitatif dengan tujuan mendapatkan suatu kesimpulan dari dari permasalahan penelitian. ${ }^{8}$

Cara untuk menarik kesimpulan dari hasil penelitian menggunakan metode deduktif. Metode deduktif merupakan suatu cara penelitian yang berangkat dari faktafakta yang ditemukan di lapangan kemudian dianalisis dengan konsep-konsep teori yang digunakan dalam penelitian. ${ }^{9}$ Hasil penelitian pustaka maupun lapangan ini dilakukan pembahasan secara deskriptif analitis. Deskriptif adalah pemaparan hasil penelitian dengan tujuan agar diperoleh suatu gambaran yang menyeluruh namun tetap sistematik terutama mengenai fakta yang berhubungan dengan permasalah yang akan diajukan dalam usulan penelitian ini. Analitis artinya gambaran yang diperoleh tersebut dilakukan analisis dengan cermat sehingga dapat diketahui tentang tujuan dari penelitian ini sendiri yaitu membuktikan permasalahan sebagai mana telah dirumuskan dalam perumusan permasalahan yang ada pada latar belakang usulan penelitian ini.

${ }^{7}$ Pedoman Penulisan Usulan Penelitian dan Tesis, 2009, Program Studi Magister Ilmu Hukum, Program Pascasarjana Universitas Semarang, Semarang, hlm. 6.

${ }^{8}$ Sudarwan Denim, 2002, Menjadi Peneliti Kualitatif, Pustaka Setia, Bandung, hlm.62.

${ }^{9}$ Ibid, hlm 63. 


\section{PEMBAHASAN}

\section{Bantuan Hukum Secara Probono Berdasarkan Undang-Undang Nomor 18 Tahun 2003 Tentang Advokat}

Peran advokat sebagai penegak dan penasehat hukum memiliki peran yang strategis dalam pelaksanakan bantuan hukum, terutama untuk mewujudkan prinsip equality before the law dan presumption of innocence. Pasal 37 UU No. 14 Tahun 1970 dan Pasal 56 ayat (2) KUHAP mengatur bahwa penasehat hukum sebagai pihak yang memberikan bantuan hukum. Oleh karena itu, materi muatan mengenai bantuan hukum menjadi sangat penting untuk diatur dalam Undang-undang yang khusus mengatur tentang advokat, yaitu Undang-Undang No. 18 Tahun 2003 (UU Advokat).

Bab VI UU Advokat mengatur secara khusus mengenai bantuan hukum cumacuma. Walaupun diatur dalam satu bab tersendiri, ketentuan mengenai bantuan hukum hanya ada satu pasal yang terdiri dari dua ayat, yaitu mengatur mengenai prinsipnya dan mengenai pengaturan lebih lanjut dalam Peraturan Pemerintah. Pasal 22 ayat (1) menyatakan bahwa advokat wajib memberikan bantuan hukum secara cuma-cuma kepada pencari keadilan yang tidak mampu. Ketentuan itu menjadi sangat penting dalam pelaksanaan bantuan hukum karena menjadi pijakan kuat kewajiban advokat. Sayangnya, kewajiban itu tidak disertai dengan mekanisme pengawasan yang jelas dan tegas, sehingga kewajiban itu tidak pernah berjalan dengan maksimal.

Lima tahun sejak pengesahan UU Advokat, peraturan pelaksanaannya baru disahkan, yaitu Peraturan Pemerintah (PP) No. 83 Tahun 2008 tentang Persyaratan dan Tata Cara Pemberian Bantuan Hukum Secara Cuma Cuma. Dalam PP itu diatur tata cara atau mekanisme untuk mendapatkan bantuan hukum. Namun, seperti UU Advokat, mekanisme pengawasan pelaksanaan bantuan hukum masih lemah. Pengawasan atas pelaksanaan bantuan hukum menjadi tanggung jawab dari organisasi advokat, dan tidak ada tanggung jawab dari negara. Semangat korps yang tinggi membuat pengawasan dan penindakan terhadap advokat yang tidak menjalankan kewajiban menjadi lemah, disamping pelaksanaan bantuan hukum tidak cukup menguntungkan bagi para advokat.

Advokat dalam kedudukannya sebagai suatu profesi yang mulia atau lebih 
e-ISSN : 2621-4105

dikenal dengan istilah officium nobile. ${ }^{10}$ Maka Advokat berdasarkan undang-undang advokat memiliki kewajiban dalam memberikan bantuan hukum. Secara ideal dapat dijelaskan bahwa Bantuan Hukum merupakan tanggung jawab sosial dari Advokat. Dalam hal Advokat tidak melakukan kewajiban profesinya maka dapat dikategorikan telah melakukan perbuatan yang bertentangan dengan kewajiban profesi sehingga dapat diberlakukan sanksi. ${ }^{11}$ Mengenai dasar hukum emberian bantuan oleh Advokat secara cuma-cuma diatur dengan Undang-Undang No. 18 tahun 2003 tentang Advokat dan Peraturan Pemerintah No. 83 Tahun 2003 tentang Persyaratan dan Tata Cara Pemberian Bantuan Hukum Secara Cuma-Cuma. Adapun isi dari masing-masing peraturan mengenai dasar hukum kewajiban seorang Advokat terkait dengan Bantuan Hukum secara Cuma-Cuma adalah :

Pasal 22

(1) Advokat wajib memberikan bantuan hukum secara cuma-cuma kepada pencari keadilan yang tidak mampu.

(2) Ketentuan mengenai persyaratan dan tata cara pemberian bantuan hukum secara cuma- cuma sebagaimana dimaksud pada ayat (1), diatur lebih lanjut dengan Peraturan Pemerintah.

Pasal 2 PP No. 83 tahun 2008 tentang Persyaratan dan Tata Cara Pemberian Bantuan Hukum Secara Cuma-Cuma, menyebutkan :

Pasal 2

Advokat wajib memberikan Bantuan Hukum Secara Cuma-Cuma kepada pencari Keadilan.

Pasal 12 ayat (1)

Advokat dilarang menolak permohonan Bantuan Hukum secara cuma-cuma

Sebagai bentuk pelayanan terhadap masyarakat, advokat diwajibkan memberikan bantuan hukum, sehingga mekanisme pemberian bantuan hukumnya

${ }^{10}$ Pasal 8 huruf a Kode Etik Advokat Indonesia, yang menyatakan bahwa : Profesi Advokat adalah profesi yang mulia dan terhormat (officium nobile), oleh karena itu dalam menjalankan profesi selaku penegak hukum dipengadilan sejajar dengan jaksa dan hakim, yang dalam melaksanakan profesinya berada dibawah perlindungan hukum, undang-undang dank ode etik.

${ }^{11}$ Pasal 7 huruf h Kode Etik Advokat Indonesia 
e-ISSN : 2621-4105

pun telah diatur yaitu melalui PP No. 83 tahun 2008 tentang Persyaratan dan Tata Cara Pemberian Bantuan Hukum Secara Cuma-Cuma.

Pasal 4

(1) Untuk memperoleh Bantuan Hukum Secara Cuma- Cuma, Pencari Keadilan mengajukan permohonan tertulis yang ditujukan langsung kepada Advokat atau melalui Organisasi Advokat atau melalui Lembaga Bantuan Hukum.

(2) Permohonan sebagaimana dimaksud pada ayat (1) sekurang-kurangnya harus memuat:

a. nama, alamat, dan pekerjaan pemohon; dan

b. uraian singkat mengenai pokok persoalan yang dimohonkan bantuan hukum.

(3) Dalam permohonan sebagaimana dimaksud pada ayat (2), Pencari Keadilan harus melampirkan keterangan tidak mampu yang dibuat oleh pejabat yang berwenang.

Pasal 5

Permohonan Bantuan Hukum Secara Cuma-Cuma dapat diajukan bersama-sama oleh beberapa Pencari Keadilan yang mempunyai kepentingan yang sama terhadap persoalan hukum yang bersangkutan.

Pasal 6

(1) Dalam hal Pencari Keadilan tidak mampu menyusun permohonan tertulis, permohonan dapat diajukan secara lisan.

(2) Permohonan yang diajukan secara lisan dituangkan dalam bentuk tertulis yang ditandatangani oleh pemohon dan Advokat atau petugas pada Organisasi Advokat atau Lembaga Bantuan Hukum yang ditugaskan untuk itu.

(3) Permohonan bantuan hukum yang diajukan langsung kepada Advokat, tembusan permohonan disampaikan kepada Organisasi Advokat.

\section{Bantuan Hukum Secara Probono Berdasarkan Undang-Undang nomor 16 tahun 2011 tentang Bantuan Hukum}

Undang-Undang No. 16 Tahun 2011 pada umumnya mengatur penyelenggaraan 
pemberian bantuan hukum melalui pemberi bantuan hukum (organisasi bantuan hukum). Negara berperan memberi dukungan dalam menjamin pelaksanaan bantuan hukum. Undang-Undang No. 16 Tahun 2011 terdiri atas 11 bab, meliputi: Ketentuan Umum, Ruang Lingkup, Penyelenggaraan Bantuan Hukum, Pemberi Bantuan Hukum, Hak dan Kewajiban Penerima Bantuan Hukum, Syarat dan Tata Cara Pemberian Bantuan Hukum, Pendanaan, Larangan, Ketentuan Pidana, Ketentuan Peralihan, dan Ketentuan Penutup.

Dalam pengaturan ruang lingkup pemberian bantuan hukum, menurut UU Bantuan Hukum diberikan kepada penerima bantuan hukum yang menghadapi masalah hukum. Dimana masalah hukum tersebut ditentukan secara limitatif yaitu (i) masalah hukum keperdataan, (ii) pidana, dan (iii) tata usaha negara, baik litigasi maupun non litigasi.

Selain itu, UU Bantuan Hukum juga mengatur syarat dan tata cara pemberian bantuan hukum. Untuk memperoleh bantuan hukum, pemohon bantuan hukum harus memenuhi syarat-syarat: ${ }^{12}$

1) Mengajukan permohonan secara tertulis yang berisi sekurang-kurangnya identitas pemohon dan uraian singkat mengenai pokok persoalan yang dimohonkan bantuan hukum;

2) Menyerahkan dokumen yang berkenaan dengan perkara; dan

3) Melampirkan surat keterangan miskin dari lurah, kepala desa, atau pejabat yang setingkat di tempat tinggal pemohon bantuan hukum.

Meski terdapat syarat bahwa permohonan harus diajukan secara tertulis, Pasal 14 ayat (2) UU Bantuan Hukum memberikan pengecualian. Jika pemohon bantuan hukum tidak mampu menyusun permohonan secara tertulis, maka permohonan dapat diajukan secara lisan.

Permohonan yang telah diajukan dan dinyatakan lengkap, oleh pemberi bantuan hukum, harus diberikan jawaban menerima atau menolak dalam waktu 3 (tiga) hari kerja. Apabila permohonan diterima, pemberi bantuan hukum memberikan bantuan hukum berdasarkan surat kuasa khusus dari penerima bantuan hukum. Sebaliknya, apabila permohonan ditolak, pemberi bantuan hukum mencantumkan alasan

\footnotetext{
${ }^{12}$ Pasal 14 UU Bantuan Hukum.
} 
e-ISSN : 2621-4105

penolakan. Pengaturan lebih lanjut mengenai syarat dan tata cara pemberian bantuan hukum diatur dengan Peraturan Pemerintah.

Dalam konteks pendanaan, UU Bantuan Hukum menyatakan penyelenggaraan bantuan hukum dibebankan kepada Anggaran Pendapatan dan Belanja Negara (APBN). Alokasi dana APBN untuk penyelenggaraan bantuan hukum adalah wujud kewajiban pemerintah dan disalurkan melalui anggaran Kementerian Hukum dan HAM. Sumber pendanaan bantuan hukum lain dapat berupa hibah atau sumbangan serta sumber pendanaan lain yang sah dan tidak mengikat. Selanjutnya pengaturan lebih lanjut mengenai tata cara penyaluran dana bantuan hukum diatur dengan Peraturan Pemerintah. ${ }^{13}$

UU Bantuan Hukum juga menyatakan bahwa daerah dapat mengalokasikan anggaran penyelenggaraan bantuan hukum dalam Anggaran Pendapatan dan Belanja Daerah (APBD). Pengaturan lebih lanjut dari pengalokasikan dana dalam APBD tersebut diatur dengan Peraturan Daerah. ${ }^{14}$

\section{Reposisi Bantuan Hukum Secara Probono Oleh Organisasi Bantuan Hukum} Dalam Kajian Undang-Undang Nomor 16 Tahun 2011 Tentang Bantuan Hukum

Perbandingkan undang-undang yang mengatur konsep bantuan hukum di UU No. 18 Tahun 2003 tentang Advokat Jo. PP No.83 Tahun 2008 tentang Persyaratan dan Tata Cara Pemberian Bantuan hukum Secara Cuma-Cuma dengan UU No. 16 Tahun 2011 Tentang Bantuan hukum Jo. PP No.42 Tahun 2013 tentang Syarat dan Tata Cara Pemberian Bantuan Hukum dan Penyaluran Dana Bantuan Hukum sangat jelas perbedaannya. Sebelum kita pahami lebih lanjut perbedaannya, kita perlu memahami arti cuma-cuma dalam pemahaman bantuan hukum.

Apabila kita cermati antara UU No. 18 Tahun 2003 Jo. PP No.83 Tahun 2008 dengan UU No. 16 Tahun 2011 Jo. PP No.42 Tahun 2013, tendapat dua konsep bantuan hukum yang secara Material berbeda dalam memahami arti kata cuma-cuma.

Cuma-cuma memiliki dua arti, cuma-cuma berasal dari kata dasar cuma. Cumacuma adalah sebuah homonym karena artinya memiliki ejaan dan pelafalan yang

\footnotetext{
${ }^{13}$ Pasal 16, Pasal 17, dan Pasal 18 UU Bantuan Hukum.

${ }^{14}$ Pasal 19 UU Bantuan Hukum.
} 
e-ISSN : 2621-4105

sama tetapi maknanya berbeda. Cuma-cuma memiliki arti dalam kelas adverbial atau kata keterangan sehingga cuma-cuma dapat memberikan keterangan kepada kata lain. Arti cuma-cuma yang pertama adalah tidak ada gunanya; sia-sia sedangkan arti cumacuma yang kedua, cuma-cuma berarti tidak perlu membayar; tidak dikenakan (dipungut) bayaran; gratis. ${ }^{15}$

Berkaitan dengan pembahasan pada BAB ini, cuma-cuma lebih diartikan pada definisi yang kedua yaitu cuma-cuma berarti tidak perlu membayar; tidak dikenakan (dipungut) bayaran; gratis. hal ini secara harfiah bisa dilihat pada definisi bantuan hukum pada UU No. 18 Tahun 2003, PP No.83 Tahun 2008, UU No. 16 Tahun 2011 dan PP No.42 Tahun 2013 yang sama-sama mendefinisikan jasa hukum secara cumacuma.

Pemahaman arti Bantuan hukum cuma-cuma secara material pada UU No. 18 Tahun 2003 Jo. PP No.83 Tahun 2008 dengan UU No. 16 Tahun 2011 Jo. PP No.42 Tahun 2013 selain pada definisinya juga bisa kita lihat pada subtansi batang tubuhnya yang berkaitan dengan pendanaan bantuan hukum dimana pada batang tubuh UU No. 18 Tahun. 2003 Jo. PP No.83 Tahun 2008 tidak ada satu pasal pun yang menyebutkan tentang sumber pendanaan bantuan hukum, selain itu pada asal 10 PP No.83 Tahun 2008 menyebutkan :

Pasal 10

Advokat dalam memberikan Bantuan Hukum Secara Cuma-Cuma harus memberikan perlakuan yang sama dengan pemberian bantuan hukum yang dilakukan dengan pembayaran honorarium.

Pasal 10 PP No.83 Tahun 2008 adalah pengikat komitmen atas konsep bantuan hukum cuma-cuma atau Probono Publico pada UU No. 18 Tahun. 2003 Jo. PP No.83 Tahun 2008

Sebaliknya pada UU No. 16 Tahun. 2011 Jo. PP No.42 Tahun 2013 jelas diatur sumber dana bantuan hukumnya dan tata cara bagi pemberi bantuan hukum untuk mengakses dana tersebut. Bahkan secara eksplisit diwajibkan bagi pemerintah untuk menyediakan dana untuk penyelenggaraan bantuan hukum.

\footnotetext{
${ }^{15}$ Arti kata cuma-cuma, diakses di https://www.apaarti.com/cuma-cuma.html, pada tanggal 12 Agustus 2018 pukul 20.55 WIB.
} 
e-ISSN : 2621-4105

\section{E. PENUTUP}

Diundangkannya Undang-Undang Nomor 18 Tahun 2003 Tentang Advokat dan Undang-Undang Nomor 16 Tahun 2011 Tentang Bantuan Hukum yang mengatur tentang bantuan hukum adalah bukti hadirnya Negara dalam menegakkan prinsipprinsip Negara hukum. Didalam Undang-Undang Nomor 18 Tahun 2003 Tentang Advokat Adalah sudah merupakan kewajiban dan tanggung jawab bagi seorang advokat untuk melakukan bantuan hukum cuma-cuma kepada masyarakat tidak mampu secara ekonomi bahkan seorang Advokat dilarang menolak penanganan perkara yang dimohonkan oleh orang atau kelompok yang tidak mampu, dan ini adalah pengabdian bagi advokat. Seperti tersebut dalam pasal 22 Undang-Undang Nomor 18 Tahun 2003 Tentang Advokat dan penjelasan umumnya.

Hadirnya Undang-Undang Nomor 16 Tahun 2011 Tentang Bantuan Hukum adalah salah satu solusi bagi Pemberi Bantuan Hukum dalam hal ini Organisasi Bantuan Hukum untuk mendapatkan pendanaan atas penyelenggaraan bantuan hukum cuma-cuma atau biasa disebut dengan Probono Publico yang pengaturan pendanaan tersebut tidak dijumpai pada konsep bantuan hukum yang diatur pada UndangUndang Nomor 18 Tahun 2003 Tentang Advokat. Selain tentang pendanaan juga terdapat kerancuan pada posisi advokat, ketika seorang advokat melakukan profesinya dia terikat dengan Undang-Undang Nomor 18 Tahun 2003 Tentang Advokat termasuk ketika seorang advokat melakukan kewajibannya untuk memberikan jasa bantuan hukum juga terikat dengan Undang-Undang Nomor 18 Tahun 2003 Tentang Advokat yang tidak mengatur tentang pendanaan dalam memberikan jasa bantuan hukum (pengabdian) ${ }^{16}$. Namun dengan hadirnya Undang-Undang Nomor 16 Tahun 2011 Tentang Bantuan Hukum terdapat pergeseran nilai, Advokat melalui organisasi bantuan hukum bisa mengajukan permohonan pendanaan yang sumbernya bisa didapat dari APBN, APBD, Hibah/ Sumbangan serta Sumber lain yang sah dan tidak mengikat.

\footnotetext{
${ }^{16}$ pengabdian disebutkan dalam Penjelasan Umum Undang-Undang Nomor 18 Tahun 2003 Tentang Advokat.
} 


\section{DAFTAR PUSTAKA}

\section{BUKU}

Frans Hendra Winarta, 2000, Bantuan Hukum Suatu Hak Asasi Manusia Bukan Belas Kasihan, Elex Media Komputindo, Jakarta.

Hardijan Rusli, 2006, Metode Penelitian Hukum Normatif, Bagaimana, (Law Review Fakultas Hukum Universitas Pelita Harapan, Volume V No. 3, Jakarta.

Pedoman Penulisan Usulan Penelitian dan Tesis, 2009, Program Studi Magister Ilmu Hukum, Program Pascasarjana Universitas Semarang, Semarang.

Soerjono Soekanto dan Sri Mamudji, 2009, Penelitian Hukum Normatif Suatu Tinjauan Singkat, Cetakan ke-11, PT Raja Grafindo Persada, Jakarta.

Sudarwan Denim, 2002, Menjadi Peneliti Kualitatif, Pustaka Setia, Bandung.

Sudikno Mertokusumo, 1998, Hukum Acara Perdata Edisi kelima, Liberty Yogyakarta.

Yusriyadi, 2017, Bantuan Hukum “Kajian Empiri Implementasi Ide-Ide Hukum”, Undip Press, Semarang.

\section{A. UNDANG - UNDANG}

Undang-Undang Dasar 1945

Undang-Undang Nomor 18 Tahun 2003 Tentang Advokat.

\section{B. WEBSITE}

https://www.apaarti.com/cuma-cuma.html. 